\title{
James on the stream of language: with some remarks on his influence on Wittgenstein
}

\author{
James sobre o fluxo da linguagem: com alguns comentários sobre sua influência \\ em Wittgenstein
}

Roberta Dreon*

\begin{abstract}
This article supports a reading of the "Stream of Thought" chapter in The Principles of Psychology according to which James was not formulating an idea of linguistic meanings as private feelings occurring within the speaker's mind, but rather criticizing the habit of basically considering language an association of names, because of the misleading consequence of this assumption for our understanding of thought as primarily resulting from the sum of its discrete parts. James was suggesting the possibility of adopting a different approach to language by considering its continuous, relational or transitive aspects, instead of focusing exclusively on substantive elements. He seems to be inviting his readers to adopt an attitude towards language complementing his own holistic view of thought as continuous and involving relations. The author explores the claim that James was considering two different attitudes towards language (GAVIN, 1992, p. 69): a more critical approach and a disposition that is attentive to the dynamic, contextual and embodied shaping of the meaning of words. This reading is based on and further develops the idea that The Principles had a positive influence on Wittgenstein, rather than a merely critical one-an interpretation supported by a group of recent scholars (BONCOMPAGNI, 2012a, 2012b; GOODMAN, 2002; JACKMAN, 2006, 20017; and SANFELIX-VIDARTE, 2016).
\end{abstract}

Keywords: Dynamic theory of meaning. Linguistic atomism. Linguistic holism. Ludwig Wittgenstein. William James.

Resumo: Este artigo sustenta uma leitura do capitulo "Stream of Thought" em The Principles of Psichology segundo o qual William James não formulou uma ideia de significados linguísticos como sentimentos privados que ocorrem dentro da mente do falante, ao contrário, criticava o bábito de, basicamente, considerar a linguagem como uma associação de nomes, devido às consequências ilusórias dessa suposição ao nosso entendimento do pensamento como resultante, principalmente, da soma das suas partes discretas. James sugere a possibilidade de adoção de uma abordagem diferente da linguagem por considerar seus aspectos continuos, relacionais ou transitivos, em vez de focar exclusivamente nos elementos substantivos. Ele parece convidar seus leitores a adotar uma atitude voltada para a

* Associate Professor of Aesthetics at Department of Philosophy and Cultural Heritage, Ca' Foscari University, Venice, Italy. Email: robdre@unive.it. 
linguagem complementando sua própria visão holística do pensamento como relações contínuas e envolventes. A autora explora a afirmação de que James considerava duas atitudes diferentes para a linguagem (GAVIN, 1992, p. 69): uma abordagem mais crítica e uma disposição que está atenta à dinâmica, contextual e formação corpórea do significado das palavras. Esta leitura baseia-se na ideia, bem como outras, de que The Principles teve uma influência positiva em Wittgenstein, em vez de uma mera crítica-uma interpretação sustentada por um grupo de estudiosos recentes (BONCOMPAGNI, 2012a, 2012b; GOODMAN, 2002; JACKMAN, 2006, 20017; e SANFELIX-VIDARTE, 2016).

Palavras-chave: Atomismo linguístico. Holismo linguistico. Ludwig Wittgenstein. Teoria dinâmica do significado. William James.

Data de recebimento: $29 / 03 / 2020$

Data de aceite: $30 / 04 / 2020$

DOI: $10.23925 / 2316-5278.2020 v 21 \mathrm{i} 1 \mathrm{p} 68-82$

\section{Introduction}

In the last two decades, a number of different scholars have crucially contributed to the emergence of a rich and refined interpretation of the relationship between Wittgenstein and William James, removed from the traditional view according to which "Wittgenstein wrote his Philosophical Investigations with an open copy of The Principles of Psychology before him, especially the chapter on 'The Stream of Thought"' (GALE, 1999, p. 165). ${ }^{1}$ As Richard Gale puts it in his The Divided Self of William James, "It is this commitment to an in-principle private language that earned James the distinction of being the major whipping boy of the later Wittgenstein."

Russell Goodman supported a praiseworthy revision of this simplified view of James's influence on Wittgenstein in 2002. Certainly, there are evident divergences between James's assumptions about the philosophy of mind and private language in The Principles, on the one hand, and Wittgenstein's late work, on the other-from the Philosophical Investigations to On Certainty. Regarding the topic of this article, namely James's views of language in The Principles, Goodman grasps the most basic point when he says that Wittgenstein's exasperation in relation to James was "his belief that experience is a sufficient fundamental category" (GOODMAN, 2002, p. 64). The

1 See BONCOMPAGNI, 2012a, 2012b; GOODMAN, 2002; JACKMAN, 2006 and 2017; and SANFELIX-VIDARTE, 2016.

2 Anna Boncompagni mentions even Peter Hacker's commentary on the Philosophical Investigations (HACKER, 1990) as a mere “[...] negative counterpart of Wittgenstein's ideas; more specifically, he depicts James's idea of the stream of consciousness as "philosophical confusion"” (BONCOMPAGNI, 2012b, p. 37). An entirely critical view of Wittgenstein's reading of The Principles is also put forward by Stephen Hilmy (1987).

3 Almost all scholars focus on James's influence on the later Wittgenstein. Differently, Vicente Sanfelix-Vidarte explores the presence of James in Wittgenstein's first work, the Tractatus Logico-Philosophicus, by focusing on two crucial topics: psychologism and the self (SANFELIX-VIDARTE, 2016). 
trouble for Wittgenstein was James's desire to consider experience independently from concepts, words and practices (GOODMAN, 2002, p. 70) - a metaphysical hypothesis that could not agree with Wittgenstein's focus on how grammatical features shore up human experiences of the world (PERISSINOTTO, 2016).

However, Wittgenstein was probably interested in the tensions- "the cobweb of metaphysics" in which James was wriggling (WITTGENSTEIN, 2000, \$165, p. 150-151) and from which Wittgenstein himself had hardly managed to free himself. Consequently, a fruitful interpretative approach is to view Wittgenstein as trying to think with and through James (including his mistakes and ambiguities) rather than against him. Positively, Goodman claims that Wittgenstein probably appreciated one major aspect in James's treatment of language in the "Stream of Thought" chapter, namely his insight that thought is not a disembodied process but one that unfolds through words. Indeed, words have a kind of individual physiognomy and quality in one's own mother tongue, they are not simply replaceable with another word, as is instead the case with musical phrases and the verses of a poem. ${ }^{4}$

Henry Jackman discusses the issue of the "if-feeling" explored in the "Stream of Thought" chapter in a couple of insightful papers (JACKMAN, 2006 and 2017). He claims that it is inappropriate to attribute to James the thesis that the meaning of words such as "if" or "and" consists in the feeling arising in one's own mind when pronouncing the word. He also affirms that it is dubious that Wittgenstein attributed such a theory of meaning to James. In those pages of The Principles, James was rejecting a "crudely empiricist theory of meaning" (JACKMAN, 2006, p. 2) in favour of a holistic claim. Jackman also rejects an interpretation of James's psychological philosophy as involving an acceptance of an in principle private language. Considering the chapter on "Conception", he says that for James an idea is not about something because it resembles that thing, but because of its capacity to act on it. Jackman concludes that "Since this 'acting upon' takes place in an external (and public) environment, there is no reason to treat the resultant meanings as "private"' (JACKMAN, 2017, p. 184).

I agree with Jackman that, in chapter 9, James is not endorsing a theory according to which meaning consists in a feeling within the mind of the speaker, but I suggest framing James's observations within a two-sided view of language. In The

4 This is an important point to which I will be returning later on. Goodman stresses that further features of James's philosophical stance in The Principles probably attracted Wittgenstein's attention. One of these features is James's idea of the primacy of practice over theory, which is to say the claim that our intellect is entirely "[...] built up of practical interests" (JAMES, 1981, p. 941). Goodman finds a convergence even between Wittgenstein's emphasis on the role of basic beliefs and our "inherited background" in $O n$ Certainty (Wittgenstein, 1969, \$ 94) and James's focus on common sense in Pragmatism (JAMES, 1981, p. 83)—on this subject, see also Boncompagni's interesting paper "The Mother-tongue of Thought: James and Wittgenstein on Common Sense", published by Cognitio (BONCOMPAGNI, 2012a). A third important common aspect is connected with James's insight that we can understand an interlocutor also without the absence of the will to act by relying on the context of the utterance. Of course, in James's case the context is mainly a psychological one; differently, Wittgenstein considers the context an established system of practices and rules of actions (GOODMAN, 2002, p. 122). However, both of them emphasized "[...] the variety of cases of willing" and offered "deflationary accounts with regards to acts of will" (GOODMAN, 2002, p. 80). 
Principles, he was criticizing the habit of considering language to basically consist in an association of names, a long-standing and widespread belief, because of the misleading consequences of this assumption in terms of understanding of thought. Seeing language as something basically composed of substantive parts gives rise to a conception of thought as primarily resulting from the sum of discrete parts-i.e. to the atomistic view of thought he was discussing and rejecting in favour of a holistic view of thought as continuous and involving relations. However, there is something more in James's exploratory attitude towards different aspects of language that Wittgenstein may have found attractive. By criticizing atomistic theories of thought and language, James shifts the focus to relations and continuities in language, invites the reader to consider different kinds of words and different nuances of meaning, and suggests an image of language too as a stream, rather than as a sum of discrete names with sharp boundaries. In other words, he invites his readers to adopt an attitude towards language complementing his holistic view of thought as continuous and involving relations.

I have developed this kind of interpretative key by following an insight found in William Gavin's book William James and the Reinstatement of the Vague, where the author claims that James fluctuates between two opposite views of language: a first critical stance, taking language as static and inadequate, and a second positive attitude, assuming language as a dynamic and "focus-fringe directional continuum" (GAVIN, 1992, p. 75). Maybe Wittgenstein was able to see that, beyond his criticism of the traditional account of language as consisting in names, James suggested an alternative, deeply contextual and embodied view of words.

\section{The standard view}

Before presenting my ideas about a different reading of James's chapter on the stream of thought, I will briefly present the standard interpretation of the subject.

In section 11 of his Philosophical Investigations, Wittgenstein is usually seen to implicitly criticize the conception of meaning presented in The Principles of Psychology, where James allegedly confused meanings with feelings (GOODMAN, 2002, p. 119). More precisely, James would be a supporter of the claim that the meaning of a word is something, i.e. that it is a kind of mental or psychological entity, preceding the linguistic exchange within a given practice. James would support the assumption that the meaning of words such as "if", "next" or "Wait!" consists in the correspondent feelings occurring within the speaker's mind. In his Brown Book, when speaking about Saint Augustine's view of language, Wittgenstein concedes to James that we can think of the meanings of words in two ways: either as states of mind or "[...] as the role which these signs are playing in the system of language" (WITTGENSTEIN, 1964, p. 78). According to Russell Goodman's reconstruction of the standard interpretation (GOODMAN, 2002, p. 121), Wittgenstein attributed to James a failure to distinguish between these two meanings of meaning, which is to say a failure to conflate the psychological and the grammatical dimensions of meaning. The philosopher's job is to specify a word grammar by discriminating its different meanings in a language, namely its variety of uses in different contexts and practices (WITTGENSTEIN, 1969, \$61). Problems in psychology and the philosophy of mind 
arise because of the overlapping of two different linguistic games or vocabularies: psychological concepts are envisaged as if they were theoretical concepts, intended to name and denote certain kinds of entities (STEINER, 2019, p. 150). By contrast, psychological concepts belong to a linguistic game that is completely different from the linguistic practice of natural science: they are to be found in ordinary life and everyday conversations, being more similar to the concepts involved in the speech of old women taking care of sick persons than to physicians' utterances (PERISSINOTTO, 2018, p. 218-219; PERISSINOTTO, 2019a, p. 24). Psychological concepts are vague compared to scientific ones, because they reflect a different logic and fit practices of a different kind. They become confused and give rise to philosophical puzzles when they are treated as scientific concepts and when inappropriate precision standards are applied to them (PERISSINOTTO, 2019b).

In the following sections of this article, I will suggest that, on the contrary, James was trying to focus on the positive vagueness of words in ordinary language, and their dynamic and holistic functioning. For the moment, however, let's complete our critical overview of the chapter on the stream of thought.

In his Philosophical Investigations, \$348, Wittgenstein criticized James's idea of the priority of thinking over language, especially with reference to the famous case of a Mr. Ballard, considered by James both in The Principles (JAMES, 1981, p. 256 ff.) and in James's essay on "Thought Before Language" (JAMES, 1982). Ballard was a deaf-mute who had been ascribed the capacity to formulate abstract thoughts about God and the world before learning the language of signs. "Wittgenstein's critique", Goodman says,

[...] is directed at a picture of thought as entirely divorced from behaviour, including verbal behaviour. Despite its difficulties, this picture remains a permanent temptation, even for someone like James who provides so many examples of thought in, rather than separate from, language (GOODMAN, 2002, p. 127).

Goodman argues that James was basically wrong in supporting this claim for reasons that Wittgenstein did not explicitly state, although he could have. In Mr. Ballard's reconstruction of his own experience, it is clear that his ideas about the world rose out of an already communicative context, made of shared practices within the narrow group of intimates he lived with, who spoke with him both verbally and by means of gestures, even if Ballard was not able to utter words properly.

I share Goodman's opinion on this point and believe that in The Principles, as well as of experience in the Essays on Radical Empiricism, James basically conceived of thought as previous to language. This is an important point to acknowledge for those who have an interest in the relationship between experience and language within the pragmatist tradition, because it marks a departure compared to both Dewey's and Mead's views of language, which assumed language to play a crucial role in the emergence of human thought (cf. DREON, 2014, 2019b).

At the same time, it cannot be denied that within the chapter on the stream of thought, solipsism and methodological individualism are still prevalent and introspection is attributed a privileged status when it comes to approaching the mind. Thinking is believed to occur within the interior theatre of the mind: James overtly speaks of the "absolute insulation" (JAMES, 1981, p. 221) of consciousness, 
as well as of the divide between different personal minds as "the most absolute breaches in nature." James's later essay "Does Consciousness Exist?" (JAMES, 1976) will represent an explicit break with his previous official stance, even if tensions and fluctuations could be already be found within The Principles, especially in the chapter on habits, as noted by John Dewey (in DEWEY, 1988).

Nonetheless, these aspects are not the main targets of the present inquiry. Rather, my purpose is to consider an alternative reading of this chapter of The Principles, focused on those linguistic features displaying the capacity of language to express the continuum of thought, as opposed to conveying a picture of thought as made up of discrete parts. Apparently, James seems to waver incoherently between two opposite positions (GAVIN, 1992, p. 69), but I think this is a false impression: despite a first negative judgement about the allegedly misleading influence of language on thought, James reveals a different and qualitatively richer approach to language, complementing his image of its different modes of functioning.

\section{James's criticism of the role of language in favouring an atomistic view of thought}

James's overt polemical target in the chapter on the stream of thought is an atomistic conception of thought as primarily composed of discrete units. But "[...] what we experience are things in relations [says Henry Jackman] and we typically no more have a separate experience of things than we do of the relations themselves" (JACKMAN, 2017, p. 180). At first glance, James's position seems to be a clear condemnation of language, whose structure leads us to think that thought is the sum of discrete units-namely, either sensations or mental states corresponding to things in the world. The leading assumption of James's argument is a criticism of the atomistic conception of the mind as consisting of simple mental states, such as sensations, whose composition would give rise to higher levels of mental activity. Already in The Principles, as well as later on in the Essays on Radical Empiricism, James proposes his critique of the empiricist assumption as a critique from within this tradition: by envisaging thought as resulting from the mere association of elemental parts, traditional empiricism would not be faithful to the empirical method. Instead of looking at thought, empiricists projected an atomistic picture onto it, illegitimately assuming that it should be composed of discrete parts and, consequently, trying to identify what those parts are. James explicitly refers to Locke's search for "simple ideas", which is to say for "mental atoms or molecules" (JAMES, 1981, p. 225), and to Hume's denial of "the reality of most relations out of the mind as well as in it" (JAMES, 1981, p. 237). ${ }^{5}$ James's rebuttal of the picture of thought as consisting of simple ideas or other discrete mental states-one should include even feelings among elemental mental states_-is drastic: "A permanently existing 'idea' or 'Vorstellung' which makes its appearance before the footlights of consciousness at periodical intervals, is as mythological an entity as the Jack of Spades" (JAMES, 1981, p. 230).

On the contrary, "Look at the variety of ways in which your thinking occurs" could be James's indictment of classical empiricists in a quasi-Wittgenstenian style.

5 A strong criticism of the atomistic approach to experience was also supported also Dewey, specifically in his essay The Need for a Recovery of Philosophy (DEWEY, 1980), which shows traces of his readings of James. 
If we consider the way in which thought proceeds in us, we must acknowledge, according to James, that we never experience simple sensations in themselves, but rather an incessant flow of thought, which certainly dwells on substantive parts, but also proceeds from one part to another, and that these transitions are also integral parts of its continuous flow. ${ }^{6}$

The things are discrete and discontinuous; they do pass before us in a train or chain, making often explosive appearances and rendering each other in twain. But their comings and goings and contrasts no more break the flow of the thought that thinks them than they break the space and the time in which they lie (JAMES, 1981, p. 233).

Apparently, a strong point of divergence between James and Wittgenstein is the fact that for the American philosopher this kind of focus on the functioning of thought is assumed as prior to language. However, James's view is a bit different: his claim is that our approach to thought is basically distorted by language; better still: our experience of thought is shaped by our approach to language as fundamentally consisting of names. He states that it is because of the "[...] whole organization of speech" (JAMES, 1981, p. 230) that we get the misleading belief about ideas or mental representations as constituting thought and corresponding to things in the real world. Since we use names to indicate things, we tend to regard ideas as corresponding to names or representations in the mind and thought as consisting of a series of discrete representations. For example, we never perceive thunder as an isolated phenomenon apart from the storm and the environment in which it is occurring. Differently, it occurs as thunder abruptly breaking the silence and contrasting with it. However, "[h]ere, again, language works against our perception of the truth. We name our thoughts simply, each after its things as if each knew its own thing and nothing else" (JAMES, 1981, p. 234): the belief that thought results from the sum of discrete entities (such as representations or mental states) arises from the way we talk, which is to say from our habit of naming things and of considering language chiefly a tool to assign names to things. "Empiricists"-who are explicitly mentioned in the following passage-tend to be blind to any different approach to language and suppose that "[...] where we have a separate name, a separate thing must needs be there to correspond with it" (JAMES, 1981, p. 238). Consequently, "[...] so inveterate has our habit become of recognizing the existence of the substantive parts alone, that language almost refuses to lend itself to any other use" (JAMES, 1981, p. 238). This little word "almost" could be read as an open window through which James tries to show an alternative perspective on the uses and functioning of language.

\section{Seeing language differently}

If we read James's text more carefully, it seems that he is not criticizing language as a whole because it causes an artificial fragmentation of thought. Rather, James's

6 On the conception of conscious life as a continuum, see GURWITSCH, 1943, p. $449 \mathrm{ff}$. 
criticism concerns one prevailing conception of language as consisting essentially of names. If we pay attention to this important point, it becomes clearer why there are so many positive appraisals of language within the chapter, despite James's criticism of the atomistic view of language and its noxious influence on our conception of thought. Therefore, I think it is possible to keep together the two different approaches to language in James's philosophy, which are characterized as mutually opposed by William Gavin in his book The Reinstatement of the Vague. ${ }^{7}$ As suggested in the previous section, it could even be said that James here is inviting us to observe a series of ways in which language and verbal structures work, by looking at them from a different approach, alternative to a name-centered focus on language. He is asking us to look at the continuous, relational or transitive aspects of language, rather than focusing exclusively on substantive elements. In this way, he is already adopting the empirical method more consistently than the empiricists ${ }^{8}$ - a method that does not seem so far from Wittgenstein's research style in the Philosophical Investigations, which takes the form of "[...] a movement from the explanatory to the descriptive," as Russell Goodman succinctly puts it (GOODMAN, 2002, p. 85).

Truth be told, James hardly goes into details with regard to this point and his arguments remain largely metaphorical-possibly there was also a real difficulty in trying to express the mainly holistic features of language by analytic means. Metaphors were probably part of his strategy to work for "[...] the reinstatement of the vague" also from a stylistic point of view (JAMES, 1981, p. 246).

In any case, James suggests some interesting lines of investigation into the complexity of speech. By contrast to our compulsory habit to segment thinking into a series of representations in correspondence with the names of things, he presents a series of observations on feelings of relation and tendencies in speech, as well as on the linguistic fringes accompanying only apparently sharply bounded names. Hence, he compares our tendency to look almost exclusively at names to the act of exclusively concentrating on a drop of water, while forgetting that it derives from a snowflake we caught with our warm hands and that it is going to evaporate in a few seconds (JAMES, 1981, p. 237).?

There is a change of perspective in the way James looks at language after his famous passage comparing the flow of consciousness to the life of a bird, as an

7 In any case, William Gavin has the crucial merit of having showed that James's remarks are insights into the possibilities and limits of language-a perspective that has generally been overlooked in favor of other interpretations of James's stream of consciousness (from GURWITSCH, 1943, to more recent inquiries such as BAILEY, 2000).

8 From this point of view, there might be an important continuity between The Principles and James's later desire to radicalize empiricism by suggesting that relations are real parts of our experience of the world-at least as real as things and substantive units (JAMES, 1976).

9 In Experience and Nature, Dewey will say that philosophers have a tendency to implicitly select specific phases of an experience, especially the results of a process of inquiry - in itself, a fully legitimate operation to perform for specific purposes-and to hypostatize them or assume them as the first components of reality, which constitutes a kind of philosophical fallacy. He succinctly describes "the philosophical fallacy" as "the conversion of eventual functions into antecedent existence" (DEWEY, 1981, p. 34). 
alternation of flights and rests or stops (JAMES, 1981, p. 236). Language no longer appears to be an obstacle for the continuity of thought, because a shift of attention occurs from nouns to linguistic rhythm, and to the flow of sentences and clauses, which is not considered a merely optional or supra-segmental character, but rather something that contributes to making names meaningful.

James invites the reader to shift his attention to conjunctions, prepositions, adverbial phrases, and syntactic forms, as well as voice inflections (JAMES, 1981, p. 238). He says that through these different linguistic aspects, "[...] it is the real relations that appear revealed" (JAMES, 1981, p. 238). Evidently, a focus on conjunctions, for example, does not fit the habit of pairing a separate name with a separate thing and a separate representation. When language is conceived as primarily consisting of names, conjunctions create some problems and must be reinterpreted as playing a mere ancillary role. Differently, focusing primarily on conjunctions, adverbial phrases and so on could help us dismantle substantivizing and hypostatizing habits of thought.

Unfortunately, James's formulas on a "feeling of and" and a "feeling of if" (JAMES, 1981, p. 238) were slippery and potentially misleading, because they could be taken to imply that James was supporting the theory that the meaning of words consists in feelings. According to this view, meanings consist primarily in states of the mind, with feelings being conceived as a further kind of mental state beyond the representations of things. As has been previously said, this is the source of the standard view of James as the "whipping boy" of section XI of the Philosophical Investigations. However, I think that this kind of reading would be inconsistent with the general anti-atomistic view of thought James was supporting here. An interpretation of this sort would amount to indulging in the tendency to privilege names, to hypostatize them and to believe that thought is composed through the association of mental states (of discrete feelings in some cases and mental representations of things or ideas in others) - a tendency criticized by James himself in these pages. As Jackman puts it, James never assumed that a single, permanent feeling is associated with a word (JACKMAN, 2006, p. 4). More decisively, interpreting the feeling of "if" as the mental state corresponding to the word "if" would go against James's main aim in the "Stream of Thought" chapter, namely to criticize "[...] the 'crudely empiricist' theory of meaning according to which our words are merely labels for the 'ideas' which constitute the 'meanings' of those words" (JACKMAN, 2006, p. 2). This would represent a completion of the theory of meaning as consisting in discrete mental states, integrating feelings as the kind of mental states that should be associated with words such as "no more", "yet", or "nevertheless" on the model of ideas corresponding to names.

A theory of linguistic meaning as consisting in feelings within the mind would also be difficult to reconcile with James's treatment of feelings and emotions in The Principles, where he famously denies that there is any mind-stuff preceding bodily changes (DREON, 2019a). In the chapters devoted to "The Emotions," a clear (yet in certain respects problematic) attempt is made to dismiss the image of the emotions as eminently and primarily mental states, as well as to establish an explicit-if generally overlooked-connection between the emotions and feelings of change rather than of status.

James's insistence on feelings is probably more understandable with reference to his interest in "[...] the aesthetic sphere of the mind, its longings, its pleasures 
and pains, and its emotions" (JAMES, 1884, p. 188). What is crucial here is "James's fundamental claim that consciousness is as much feeling as thought" (GOODMAN, 2002, p. 131). From his early essay on "The Sentiment of Rationality," James emphasized human passions and sentiments as central features in human activities, including cognition and evaluation, and tried to provide a complex portrayal of human rationality as including aesthetic, qualitative or affective features rather than excluding them (CALCATERRA, 2003, p. 85-86).

In a nutshell, James was not interested in a conception of meaning as consisting in feelings within the mind. Rather, he was trying to argue that in speech we hear and feel the relationships and transitions between things and events, relationships that are not entities at all, but nevertheless exist: "[N]amelessness is compatible with existence." James's emphasis in this case is not so much on the priority of existence over language, but rather on the insight that existence is to be found even where there are no names, namely where the focus is on relations rather than on entities.

James suggests also paying attention to expressions like "nothing but," "not yet," and "when?". He considers these to be "signs of the direction of thought" (JAMES, 1981, p. 244): they do not match sensory images of relatively stable things. Rather, they are signs of the functioning of language, revealing the direction of one's discourse. This kind of function is evident, according to James, when reading a text: at first glance, an expert reader is able to read a text with expressiveness, with the right emphasis and appropriate pauses, even though he does not always understand the content in detail (JAMES, 1981, p. 245).

James is also interested in the opportunity to adopt a different approach to names. Already at the beginning of his speech, he points out that we should pay attention to agglutinative languages, as well as to declensions in Latin and Greek. Linguistic phenomena of this kind show that even names are not unalterable, but change to match the context in which they appear and from which they are not independent (JAMES, 1981, p. 230). This gives James a further opportunity to emphasize the relations between words rather than isolated words, viewed as selfstanding. There is a difference between using the term "man" as a universal term and speaking about that solitary "man" who is facing us: even when dealing with names, their relations within a context play an important role in determining their meaning (JAMES, 1981, p. 248).

At a certain point, James seems to develop this contextualist view of names even further (see GAVIN, 1992, p. 72), by attributing to names a range of implications and of relations with other words. James speaks of "long association fringes of mutual repugnance or affinity" between words (JAMES, 1981, p. 251). The "fringe" or "suffusion" is not merely a feature of thought and brain processes: ${ }^{11}$ for James,

10 I do not wish to completely deny that there are some ambiguous fluctuations in James's pages, as when he claims that there is "an altogether specific affection of our mind" (JAMES, 1981, p. 245). Nonetheless, my point is that the text also supports my interpretation, which is more coherent with James's main aim in this chapter-namely, to oppose an atomistic conception of thought.

11 Interestingly, James also conceived brain processes as never occurring in isolation, but always framed within a network of other mutually conditioning neural processes. He 
it is also a linguistic feature, which plays a role in the process of determining the meaning of a word. Behind the utterance of a single word, we vaguely perceive the 'train of words' involved; in spite (or because) of their vagueness, they mark out a word in a given context with respect to a different situation. Here James suggests the famous comparison with harmonic sounds in music: even if the note is always the same, each musical instrument has a different voice because the fundamental note is merged with a series of harmonics that always give it a peculiar timbre or character. This Jamesian insight is not simply equal to the semiotic chain of references or inferences illustrated by Peirce: ${ }^{12}$ there is a difference between a word's close connections with other words within one's own mother tongue or jargon, on the one hand, and the explicit descriptive knowledge of the relations between a chain of words and thoughts, on the other hand. Here James is emphasizing the role of the only vaguely perceived relations involved in a word, whose boundaries are not sharply defined because they are ruled by affectively or aesthetically based repulsions and attractions. However, their qualitatively or affectively based selection perfectly fits several contexts: most linguistic exchanges between intimate speakers, poetry and literature, and slang situations. For sure, there are contexts requiring an analytic explication of the chains of references involved in a word, but this is a further possible experience.

I think Goodman is right to suggest an influence from James in Wittgenstein's remarks on how we experience the meanings of words (GOODMAN, 2002, p. 139141). In characterizing one word's fringe as shaped by mutual affinities with or opposition towards other words, James seems to pay attention to the embodied or material features of language and the idea of the "physiognomy of a word" examined by Wittgenstein in his Philosophical Investigations (WITTGENSTEIN, 1958 , p. 218). Speaking about "fine aesthetic difference[s]" and the capacity to feel whether a word fits a specific context or not, Wittgenstein says that "[...] it is the field of force of a word that is decisive" (WITTGENSTEIN, 1958, p. 219). In the light of this, I conclude, Wittgenstein's "field of force" does not appear all that distant from James's "fringe" of a word.

James's inquiry into the relational features of language leads to a distinction between two kinds of meaning, one considered dynamically and the other statically, or without context:

The 'meaning' of a word taken thus dynamically in a sentence may be quite different from its meaning when taken statically or without context. The dynamic meaning is usually reduced to the bare fringe we have described, or felt suitability or unfitness to the context and conclusion. The static meaning, when the word is concrete, as 'table', 'Boston', consists of sensory images

spoke of a "fringe," "psychic overtone" or "suffusion" to characterize even brain activity, precisely after his remarks on harmonic sounds in music (JAMES, 1981, p. 249). In coherence with his emphasis on brain plasticity, his view of neural functioning was longsighted and far from a modular conception of brain activity, based on pre-established neural programmes.

12 Nonetheless, it must be recalled that Peirce spoke of a kind of "emotional interpretant" existing together with "energetic" and "logical" interpretants (see EP 2:409). 
awakened; when it is abstract, as 'criminal legislation', 'fallacy', the meaning consists of other words aroused, forming the socalled 'definition' (JAMES, 1981, p. 255).

For sure, the meaning of a word can be considered a static entity, corresponding to a perceptive image, when we isolate or abstract it from the context out which it arises. Incidentally, it could be observed that in the case of abstract names, the static meaning is not a pure concept, for James, but a series of words forming a definition.

However, the most interesting issue from a Wittgensteinian point of view is James's claim that we can, and probably should, also primarily consider meaning a dynamic process or a verb-rather than a mental state preceding a linguistic utterance. In this case, a word means something according to its capacity to suit or to fit a given context, as well as some expected conclusions. The meaning of a word is not conceived here as a kind of pre-existing entity, but as determining itself through its occurrence in a web of further words.

Certainly, the context is much more psychologically coloured for James than Wittgenstein's pragmatic and socially oriented context of uses and shared practices. The normative character is lacking from James's picture. But reading section XI of the Philosophical Investigations through Jamesian lenses helps reveal Wittgenstein's interest for the sensible or qualitative features of meaning that tend to be overlooked by an eminently action- and norm-oriented interpretation of his conception of language.

\section{Conclusion}

Briefly, in this article I have contended that in the chapter on the stream of thought James was not criticizing language as a whole, but the prevailing habit of considering it to be basically composed of names and of favouring a conception of thinking as composed of discrete units rather than as a continuous flow. While emphasizing the primacy of thought over language, James was capable of looking at speech differently and of providing a richer and more nuanced conception of language. Dewey and Mead developed much more radical ideas on language and thought, but James's contribution within the group of the Classical Pragmatists should not be underestimated.

James did not support a theory of meaning as consisting of feelings within one's own private mind. On the contrary, James asked his readers to consider forms of continuity, relations, tendencies and fringes within language, i.e. to look at language by adopting a different attitude. This shift in the approach to language allows us to see its relational aspects not simply as secondary features (and problems to be overcome), according to a substantive picture of meaning, but as constituting language as a continuum and complementing James's view of thought as a stream.

Finally, James was foreshadowing a dynamic conception of the meaning of words as something occurring within the context of mutual relations between words, rather than pre-existent to linguistic utterances.

Did Wittgenstein see this complexity in James's treatment of language, in spite of James's still strong preference for the introspective attitude and his assumption of the primacy of thinking over language? 
Together with many authors I have referred to in this paper, I believe that the idea of Wittgenstein taking The Principles as a mere polemical target has definitively showed its weakness. Rather, Wittgenstein was attracted to, and inspired by, certain insights in James's complex philosophical laboratory, including the idea of the stream of language.

\section{References}

BAILEY, Andrew R. Beyond the fringe: William James on the transitional parts of the stream of consciousness. In: VARELA, Francisco; SHEAR, Jonathan (ed.). The view from within: First-person approaches to the study of consciousness. ThorvertonBowling Green: Inprint Academic, 2000.

BONCOMPAGNI, Anna. "The Mother-tongue of Thought": James and Wittgenstein on Common Sense. Cognitio: Revista de Filosofia, São Paulo, v. 13, n. 1, p. 37-60, jan./jun. 2012a.

BONCOMPAGNI, Anna. Streams and River-Beds: James's Stream of Thought in Wittgenstein's Manuscripts 165 and 129. European Journal of Pragmatism and American Philosophy, v. IV, n. 2, 2012b.

CALCATERRA, Rosa M. Sentimenti e razionalità nel pragmatismo di William James. In: CAlCATERRA, Rosa M. Pragmatismo: i valori dell'esperienza. Letture di Peirce, James e Mead. Roma: Carocci, 2003, p. 85-100.

DEWEY, John. The need for a recovery of philosophy. In: BOYDSTON, Jo Ann (ed.). The middle works (1899-1924), Volume 10: 1916-1917. Carbondale: Southern Illinois University Press, 1980, p. 3-48.

DEWEY, John. Experience and nature. In: BOYDSTON, Jo Ann (Ed.). The later works (1925-1953), Volume 1: 1925. Carbondale: Southern Illinois University Press, 1988.

DEWEY, John. The vanishing subject in the psychology of James. In: BOYDSTON, Jo Ann (Ed.). The later works (1925-1953), Volume 14: 1939-1941. Carbondale: Southern Illinois University Press, 1988, p. 155-167.

DREON, Roberta. Dewey on Language: Elements for a Non-dualistic Approach. European Journal of Pragmatism and American Philosophy, v. VI, n. 2, 2014.

DREON, Roberta. A pragmatist view of emotions: tracing its significance for the current debate. In: CANDIOTTO, Laura (ed.). The value of emotions for knowledge, Cham: Palgrave Macmillan, 2019a. p. 73-99.

DREON, Roberta. Gesti emotivi e gesti verbali: l'eredità di George Herbert Mead sulla genesi del linguaggio umano. Sistemi intelligenti, a. XXXI, n. 1, p. 119-138, aprile, $2019 \mathrm{~b}$.

GALE, Richard M. The divided self of William James. Cambridge, MA: Cambridge University Press, 1999. 
GAVIN, William Joseph. William James and the reinstatement of the vague. Philadelphia: Temple University Press, 1992.

GOODMAN, Russell B. Wittgenstein and William James. Cambridge, MA: Cambridge University Press, 2002.

GURWITCH, Aron. William James' Theory of the "Transitive Parts" of the Stream of Consciousness. Philosophy and Phenomenological Research, v. 3, n. 4, p. 449-477, June 1943.

HACKER, Peter M. S. Wittgenstein: Meaning and Mind, volume 3 An analytical commentary on the Philosophical investigations. Oxford: Blackwell, 1990.

HACKER, Peter M. S. Wittgenstein: Mind and Will, volume 4 An analytical commentary on the Philosophical Investigations. Oxford: Blackwell, 1996.

HILMY, Stephen S. the Later Wittgenstein. Oxford: Blackwell, 1987.

JACKMAN, Henry. Wittgenstein EJames's "Stream of Thought". 2006. Available on: <http://www.yorku.ca/hjackman/papers/WittJames.pdf>. Accessed on: 28.03.2020.

JACKMAN, Henry. William James on conceptions and private language. Belgrade Philosophical Annual, v. 30, p. 175-194, 2017.

JAMES, William. What is an emotion? Mind, Oxford, v. 9, Issue 34, p. 188-205, April 1884.

JAMES, William. Essays in radical empiricism. Cambridge, MA: Harvard University Press, 1976.

JAMES, William. The principles of psychology. Cambridge, MA: Harvard University Press, 1981.

JAMES, William. Thought before language: A Deaf-mute's recollection. In: JAMES, William. Essays in psychology. Cambridge, MA, and London: Harvard University Press, 1983, p. 278-291.

PEIRCE, Charles Sanders. The Essential Peirce: selected philosophical writings. Edited by HOUSER, N. et al. Bloomington: Indiana University Press, 1992-1998. 2 v. [Cited as EP followed by a number refers to volume, and page].

PERISSINOTTO, Luigi. Concept-formation and Facts of Nature in Wittgenstein. Paradigmi, n. XXXIV, p. 11-31, 2016.

PERISSINOTTO, Luigi. Introduzione a Wittgenstein. Bologna: il Mulino, 2018.

PERISSINOTTO, Luigi. Introduzione. In: WITTGESTEIN, Ludwig. Lezioni di psicologia filosofica: dagli appunti (1946-47) di Peter T. Geach. Milano-Udine: Mimesis, 2019a.

PERISSINOTTO, Luigi. La mobilità dei significati: divagazioni sulla lingua comune e le sue presunte imperfezioni logiche. Ermeneutica letteraria, Pisa, v. XV, p. 13-28, $2019 b$. 
SANFELIX-VIDARTE, Vicente. Psychologism and the self. European Journal of Pragmatism and American Philosophy, v. IX, n. 1, 2017.

STEINER, Pierre. Désaturer l'esprit: usages du Pragmatism. Paris: Questions Théoriques, 2019.

WITTGENSTEIN, Ludwig. Philosophical investigations. Oxford: Blackwell, 1958.

WITTGENSTEIN, Ludwig. The blue and brown books: preliminary studies for the philosophical investigations. Oxford: Blackwell, 1964.

WITTGENSTEIN, Ludwig. On certainty. Oxford: Blackwell, 1969.

WITTGENSTEIN, Ludwig. Wittgenstein's Nachlass: the Bergen electronic edition. Oxford: Oxford University Press, 2000. 